\title{
Identifikasi Kontributor Pengembangan Kognitif Anak Prasekolah: Guru, Teman, Lingkungan Fisik Sekolah?
}

\author{
Agustina Hendriati ${ }^{1}{ }^{\bowtie}$, Soegeng Santoso ${ }^{2}$ \\ Psikologi, Universitas Katolik Indonesia Atma Jaya ${ }^{1}$ \\ Pendidikan Ilmu Pengetahuan Sosial, Universitas Indraprasta PGRI² \\ DOI: $\underline{10.31004 / o b s e s i . v 5 i 2.757}$
}

\begin{abstract}
Abstrak
Studi ini ingin menemukan kontributor modifiabilitas kognisi anak sesuai pilar pendidikan, apakah interaksi dengan guru, teman sebaya atau lingkungan fisik TK. Subjek penelitian adalah 42 anak dan 22 guru TK di Jakarta yang dipilih secara purposif dan dirating dengan instrumen fungsi kognitif (ACFS), interaksi mediatif (MLERS dan MLE teman) serta lingkungan sekolah (ECERS-R), semuanya dalam setting alami. Data diolah dengan analisis regresi. Hasil menunjukkan anak memiliki potensi modifiabilitas kognisi khususnya terkait interaksi mediatif dengan guru dan faktor sosial ekonomi. Ditemukan juga bahwa guru masih perlu meningkatkan keterampilan memediasi perkembangan kognitif, utamanya di kelompok SES menengah bawah. Interaksi mediatif dengan teman sangat terbatas dan lingkungan sekolah belum sesuai dengan prinsip DAP. Pembahasan mengacu pada isu metodologis dan konteks Indonesia.
\end{abstract}

Kata Kunci: kognitif; modifiabilitas kognisi; interaksi mediatif; lingkungan sekolah; PAUD

\begin{abstract}
This study aimed at finding out which element/s of ECE contributes to children's cognitive modifiability. 42 children and 22 teachers in twenty-two kindergartens were purposively sampled and assessed/rated with ACFS, MLERS, MLE peer and ECERS-R in natural setting. The results from quantitative analysis indicated that children showing cognitive modifiability potential especially more in relation to teacher mediation and social economic status than as effected by other observed variables. It was also found that teachers still needed to improve their mediation skills, but more of concerns were teachers serving children from lower socialeconomy background. Mediated learning experience with peer was very limited, and the quality of school environment was not yet par to DAP standard. Both elements were insignificant in contributing to children's cognitive modifiability. The findings were discussed according to relevant research findings, methodology issues as well as the implications for the improvement of early childhood education provision in Indonesia.
\end{abstract}

Keywords: cognitive, cognitive modifiability, mediated learning experience, school environment quality, early childhood education

Copyright (c) 2020 Agustina Hendriati \& Soegeng Santoso

$\triangle$ Corresponding author:

Email Address : agustina.hendriati@atmajaya.ac.id (Jakarta, Indonesia)

Received 10 October 2020, Accepted 29 October 2020, Published 7 November 2020 


\section{PENDAHULUAN}

Mengutip pendapat Peter Drucker, Tilaar (2004) menyatakan bahwa Indonesia telah memasuki era knowledge society (masyarakat ilmu pengetahuan) yang bercirikan penggunaan rasio atau nalar dan pengembangan serta pemanfaatan pengetahuan. Belajar untuk tahu berarti pemerolehan pengetahuan yang berstruktur, bukan semata penguasaan isi pengetahuan yang tentunya cepat menjadi kuno, namun merupakan pengembangan kemampuan belajar. Sayangnya, dari hasil berbagai pengamatannya, (Buchori, 2002) menyatakan bahwa kemampuan belajar orang Indonesia umumnya masih rendah. Berdasarkan riset ekstensif, Beatty et al. (2018) bahkan mengatakan walaupun anak Indonesia saat ini sudah banyak dan lama ada di sekolah, namun learning profile (profil belajar)nya justru makin menurun. Laporan lain menyimpulkan bahwa harapan untuk dapat mewujudkan kemampuan belajar sepanjang hayat di Indonesia kiranya masih menghadapi banyak sekali tantangan (OECD/Asian Development Bank, 2015).

Sejauh ini belum banyak kajian mengenai pendidikan anak usia dini, khususnya mengenai kapasitas belajar atau fungsi kognitif anak usia dini di Indonesia. Laporan (UNESCO, 2005) mengutip hasil asesmen Bank Dunia tentang lemahnya kualitas interaksi guru dengan anak yang hanya memodelkan cara memproduksi suatu hasil, dan adanya keterbatasan bahan bermain. UNESCO menyatakan langkanya data tentang keberadaan bahan dan peralatan bermain dan perlunya meneliti kualitas interaksi guru-anak serta anak- anak dalam beragam nuansa pendidikan anak usia dini di Indonesia. Laporan tersebut juga merujuk sejumlah penelitian yang menunjukkan lemahnya stimulasi bahasa dan kognisi pada anak-anak usia dini di Indonesia. Hasil penelitian lain menunjukkan bahwa cara mengajar guru dan sistem pendidikan di Indonesia masih mementingkan hafalan daripada pemahaman (Smeru, 2016).

Dari seluruh uraian di atas, dapat disimpulkan bahwa kita perlu mengarahkan pendidikan sejak dini agar dapat mengembangkan fungsi kognitif yang mendasari kemampuan belajar dalam era perubahan dan masyarakat berbasis pengetahuan. Temuan dalam berbagai penelitian otak sudah memastikan bahwa otak manusia mempunyai kapasitas untuk berubah lebih dari sekedar perubahan akibat perkembangan normal (Geary, 2006). Persoalannya adalah apa faktor yang dapat mendorong perubahan kognitif itu.

Piaget (1950) berpandangan bahwa dengan dasar dorongan alamiah untuk beradaptasi, maka kontak anak dengan lingkungan akan memicu seorang anak untuk berubah. Jika anak berada dalam lingkungan yang kaya dan anak berkesempatan untuk mengeksplorasi lingkungan itu serta melakukan manipulasi terhadap bahan bermain/belajar yang tersedia, maka anak akan mengolah stimulus-stimulus itu dan mengorganisirnya hingga terbentuk skema baru atau struktur kognitif yang lebih tinggi kualitasnya. Dengan kata lain perubahan kognisi terjadi akibat dorongan dalam diri anak yang dipicu oleh kebutuhan untuk beradaptasi terhadap lingkungannya. Di lain pihak Vygotsky berpandangan bahwa interaksi anak dengan manusia lain secara sosiohistoris adalah faktor yang menentukan perkembangan kognitif (Hallpike \& Wertsch, 1987). Dalam zona perkembangan proksimal, perubahan kognisi menuju batas atas terjadi ketika anak dibantu oleh pihak yang lebih kompeten. 
Feuerstein, Feuerstein, dan Falik (2010) dengan teori Structural Cognitive Modifiability menyatakan bahwa manusia adalah sebuah sistem yang terbuka, adaptif, dan punya kemauan untuk berubah. Pendekatan dalam modifikasi kognisi seseorang menekankan pada perubahan yang otonom dan bersifat mengatur diri sendiri (selfregulating). Namun sebagai pengikut Vygotsky, Feuerstein juga menyatakan bahwa modifiabilitas kognisi dapat terjadi akibat faktor proksimal yang menekankan interaksi dengan orang lain dan faktor distal yang lebih luas seperti faktor sosialekonomi. Dalam hal ini modifiabilitas kognisi didefinisikan sebagai kapasitas fungsi kognitif untuk berubah mencapai potensi terbaiknya, sebagai respon terhadap stimulasi lingkungan.

Secara lebih spesifik Feuerstein et al. (2010) menyatakan bahwa interaksi antara anak dengan lingkungan (termasuk bahan/sumber belajar) tidak akan efektif sebagai proses pembelajaran jika tidak diperantarai oleh peran seorang mediator; dalam hal ini sebagai pihak lain yang lebih kompeten. Feuerstein beranggapan bahwa paparan langsung dengan bahan/sumber belajar masuk ke dalam sistem anak secara acak dalam dua hal. Pertama, tanpa perencanaan, paparan stimulus bagi anak, maka kemunculan/keberadaan stimulus itu sendiri saat dihadapi anak akan mengandung ketidak-sengajaan yang acak. Kedua adalah tingkat kesiapan anak dalam menghadapi stimulus, yang menjadi acak dan sangat bervariasi jika tidak diperantarai oleh seorang mediator (Feuerstein, Klein, \& Tannenbaum, 1994). Para ahli ini menyatakan bahwa pengalaman belajar dengan mediasi (Mediated Learning Experience/MLE atau interaksi mediatif yang digunakan sebagai istilah dalam penelitian ini), dimaknai sebagai interaksi berkualitas antara organisma dan lingkungan; kualitas dipastikan terjadi melalui seseorang yang berniat dan memposisikan diri untuk memediasi stimulus yang dihadapi organisma.

Feuerstein tegas menyatakan peranan MLE sebagai satu-satunya faktor proksimal yang menghasilkan modifiabilitas kognisi. Masalahnya masih ada keraguan apakah memang demikian adanya. Selain argumentasi berdasarkan teori Piaget, perlu disimak hasil penelitian tentang bagaimana anak belajar atau memperoleh pengetahuan dalam budaya yang berbeda. Munro dan Munro (n.d.) menunjukkan bahwa anak-anak dalam budaya tradisional cenderung belajar melalui pengamatan. Mereka banyak melakukan kegiatan sendiri tanpa bimbingan orangtua. Di sisi lain, laporan UNESCO (2005) menunjukkan bahwa guru TK di Indonesia lebih cenderung hanya memodelkan cara membuat/menghasilkan suatu keluaran. Oleh karena itu sangat mungkin mediasi guru yang komprehensif tidak menjadi lebih penting daripada keberadaan bahan dan lingkungan dengan mana anak dapat bermain sehingga mendapatkan stimulasi melalui kontak fisik yang terjadi (bermain/memainkan bahan yang ada) secara mandiri.

Budaya sudah terbukti meninggalkan jejak dalam kognisi manusia (Geary, 2005; Boduroglu, Shah, \& Nisbett, 2009), dan bahwa cara orang melakukan mediasi juga bervariasi sesuai konteks budaya (Klein, 1998; Hundeide dalam Seok-Hoon, Pou, \& Tan, 2003). Oleh karena itu tidak dapat dipastikan bahwa kualitas MLE yang diajukan oleh Feuerstein juga pasti muncul dalam konteks Indonesia. Apalagi kesimpulan efek MLE bagi kinerja kognitif dalam penelitian di Indonesia juga belum konklusif (Tiatri, 2001) - apakah MLE efektif atau tidak, dan dalam konteks serta rincian perilaku mediatif yang seperti apa. 
Berikutnya tentang siapa mediator yang lebih banyak berperan. Wajar dipahami bahwa guru akan menjadi pihak yang lebih kompeten yang memberikan mediasi terbaik bagi anak di lingkungan sekolah. Namun, sebagaimana dinyatakan oleh Vygotsky dalam teori zona perkembangan proksimal, teman sebaya juga dapat menjadi pihak yang lebih kompeten dan menjadi mediator penting bagi anak. Penelitian Rogoff et al. (1993) di Amerika Selatan menunjukkan bahwa proses pembelajaran anak dalam kehidupan sehari-hari justru banyak dibantu oleh keberadaan dan dukungan saudara kandung dan teman sebaya. Penelitian Farver dan Wimbarti (1995) juga menunjukkan bahwa dalam keseharian di lingkungan rumah, anak Indonesia lebih banyak bermain bersama saudara atau teman sebaya daripada bermain bersama dan menerima bimbingan dari orangtua/ibu. Fakta semacam ini mendorong kajian untuk melihat apa yang terjadi dalam konteks sekolah.

Konsep collaborative learning, peer-tutoring, peer-assisted learning dan semacamnya sudah lama dikenal dan dipraktekkan bahkan untuk anak yang lebih muda (King, 1997; McMaster et al., 2006; Shamir \& Tzuriel, 2002). Penelitian yang dilakukan terhadap beberapa kondisi teman sebaya sebagai pihak yang memediasi belajar menunjukkan dihasilkannya modifiabilitas kognisi baik pada anak yang dimediasi maupun si mediator (Seok-Hoon et al., 2003; Tzuriel \& Shamir, 2010). Dapat disimpulkan bahwa teman sebaya memang potensial sebagai mediator pembelajaran yang dapat membantu munculnya modifiabilitas kognisi pada anak-anak. Persoalannya kemudian ada dua. Pertama adalah jika dilakukan dalam situasi natural/keseharian dalam kelas dan konteks tanpa pelatihan, teman sebaya belum tentu dapat berperan menjadi mediator pembelajaran karena tidak terlatih atau belum berkembang kemampuannya melakukan mediasi atau menyajikan rambatan kognitif bagi temannya. Kedua, walaupun mempertimbangkan bahwa teman sebaya terbukti potensial untuk memediasi modifiabilitas kognisi, peranan itu belum dapat dipastikan besarannya jika dibandingkan dengan peranan faktor-faktor lain yang juga berkontribusi terhadap modifiabilitas kognisi anak usia dini.

Telah disinggung terdahulu bahwa Piaget menganggap penting peran manipulasi obyek dalam proses anak mengkonstruksikan pengetahuan. Tugas pendidikan anak usia dini kemudian adalah menyediakan kondisi dimaksud; yaitu anak berkesempatan untuk kontak dengan obyek yang beragam/kaya, melakukan manipulasi termasuk coba-salah terhadap beragam obyek tersebut. Ketersediaan material atau bahan bermain menjadi hal yang penting dalam lingkungan pendidikan anak usia dini. Selain kekayaan bahan/peralatan, diperlukan pula rancangan kegiatan yang memungkinkan anak untuk secara maksimal mengeksplorasi lingkungan dan mengambil manfaat dari kontak tersebut untuk mengorganisir struktur kognitif mencapai level yang lebih tinggi. Montessori juga termasuk penganut pandangan bahwa kontak dengan peralatan merupakan hal yang esensial. Konsep yang diutarakannya disebut "prepared environment" di mana anak mendapat kesempatan untuk mengengksplorasi dan memanipulasi bahan-bahan yang disiapkan oleh guru/sekolah untuk merangsang perkembangan anak.

Dalam sebuah percobaan dengan tikus, Greenough et al. (dalam Jensen, 2006) membuktikan bahwa tikus yang diberi lingkungan kaya stimulasi menjadi lebih pandai daripada kelompok kontrol. Tikus dalam kelompok pengayaan mengalami peningkatan sistem pembuluh darah otak yang meningkatkan jumah oksigen ke dalam otak. Wood dan Attfield (2005) mengutip Carr dan menyatakan pentingnya lingkungan belajar (learning environment) bagi perkembangan anak. Lingkungan yang 
"high-affordance" - kaya, sesuai dan mendukung - akan dipenuhi dengan bahan dan peralatan/perlengkapan yang mendukung proses pembelajaran melalui bermain. NAEYC (2009) mengeluarkan 12 prinsip DAP yang di antaranya juga terkait kualitas lingkungan [fisik] pendidikan anak usia dini.

Dari seluruh uraian di atas tampak bahwa ada kebutuhan untuk memahami interaksi mediatif guru, interaksi mediatif teman sebaya dan kualitas lingkungan sekolah yang memungkinkan kontak stimulatif dengan bahan/perlengkapan bermain, serta bagaimana kontribusi variabel-variabel tersebut terhadap modifiabilitas kognisi anak usia dini. Pertanyaan yang diajukan dalam penelitian ini adalah: 1) Apakah interaksi mediatif anak dengan guru berpengaruh terhadap modifiabilitas kognisi anak usia dini di Jakarta? 2) Apakah interaksi mediatif anak dengan teman sebaya berpengaruh terhadap modifiabilitas kognisi anak usia dini di Jakarta? 3) Apakah lingkungan fisik sekolah berpengaruh terhadap modifiabilitas kognisi anak usia dini di Jakarta? 4) Apakah interaksi mediatif dengan guru, dengan teman sebaya, dan lingkungan fisik sekolah bersama-sama berpengaruh terhadap modifiabilitas kognisi anak usia dini di Jakarta?

\section{METODOLOGI}

Penelitian ini merupakan sebuah kajian asosiatif yang menguji kontribusi tiga variabel independen terhadap variabel dependen. Berikut gambaran sampel, instrument dan prosedur penelitian.

Penelitian dilakukan di DKI Jakarta. Sampelnya adalah 22 TK yang tersebar di lima wilayah DKI Jakarta dipilih secara purposif. Kriteria TK selain memenuhi sebaran wilayah juga mewakili kondisi sosial ekonomi anak yang dilayaninya (menengah atas dan menengah bawah). Dari setiap TK hanya diambil satu kelas TK B, di mana gurunya berpengalaman mengajar anak usia dini sedikitnya lima tahun dan berjeniskelamin perempuan untuk mengontrol faktor jenis kelamin. 42 anak dipilih dari $22 \mathrm{TK}$ itu, dengan sebaran laki-laki/perempuan yang seimbang.

Terdapat tiga instrumen utama yang digunakan dalam penelitian ini. Pertama, ACFS (Application of Cognitive Functions Scale) yang dikembangkan Lidz \& Jepsen (Haywood \& Lidz, 2006; No authorship indicated, 1993). Alat ini memberikan gambaran baseline (batas awal) fungsi kognitif \& batas atas setelah proses mediasi yang bisa dilakukan secara standar/scripted. Instrumen ini mengukur variabel modifiabilitas kognisi. Seiring dengan hasil pada studi lain, besaran Cronbach's alpha pada skor pasca-tes yang menjadi skor variabel terikat adalah 0.88.

Kedua, MLERS (Mediated Learning Experience Rating Scale) yang disusun oleh Lidz, (2003). Alat untuk mengukur interaksi mediatif guru yang digunakan di sini adalah versi pengamatan kelas/klasikal dalam setting alamiah. Cronbach's alpha data terkumpul sebesar 0.93, sedangkan reliabilitas antar rater dengan intra-class correlation one-way random untuk average measures didapatkan angka 0.82 .

Ketiga, pengukuran interaksi mediatif dengan teman sebaya, mengikuti Shamir dan Tzuriel (2002) yang memelopori kajian tentang mediasi teman sebaya dengan menggunakan OMI (Observation of Mediation Interaction) yang disusun oleh Klein (1998). Konsistensi internal sebesar 0.82 dan reliabilitas antar-rater 0.41. Angka ini signifikan tetapi memang tidak terlalu tinggi karena interaksi mediatif teman sebaya sedikit sekali kejadiannya secara alamiah di dalam kelas yang terpilih dalam penelitian ini. Posisi (duduk/berdiri) pengamat sangat menentukan dalam menangkap peristiwanya. 
ECERS-R (Early Childhood Environment Rating Scales -Revised) diciptakan oleh Harms, Clifford, dan Cryer (2005) berdasarkan standar praktik sesuai perkembangan. Untuk keperluan penelitian ini ECERS-R hanya digunakan pada subskala yang relevan pada variabel lingkungan fisik sekolah, yaitu Ruang dan Perabotan (8 butir dengan skor maksimal 56), serta Kegiatan (9 butir dengan skor maksimal 63). Pengolahan konsistensi internal menghasilkan 0.92 dan reliabilitas antar-rater sebesar 0.93 untuk skor total (mencakup kedua dimensi/sub-skala). Hasil ini seiring dengan temuan pada berbagai populasi lain yang dilaporkan dalam buku manual ECERS-R 2005.

Keseluruhan proses penelitian dilakukan dalam beberapa tahap: 1) Pengurusan perijinan dan akses sekolah; 2) Perekrutan empat rater dengan kualifikasi minimal Sarjana Psikologi atau Pendidikan dan pelatihan rater selama 2 hari; 3) Proses peleburan/penyesuaian keberadaan observer/rater dalam kelas/lingkungan sekolah yang biasanya memakan waktu sehari; 4) Masa observasi dalam kelas dan lingkungan sekolah oleh 1-2 rater (dengan fokus guru atau teman sebaya pada waktu tertentu/tidak dicampur-aduk saat pengamatan dalam kelas), dan rata-rata dilakukan dalam waktu 5 hari termasuk pengamatan untuk lingkungan fisik sekolah; 6) Pengambilan data modifiabilitas kognisi dilakukan secara individual di ruang/tempat terpisah oleh psikolog.

Kecuali asesmen modifiabilitas kognisi yang dilakukan peneliti sendiri yang sudah tersertifikasi melakukan asesmen dinamis, data terpakai (di luar penghitungan reliabilitas antar-rater) adalah hasil konsolidasi antar rater. Data kuantitatif kemudian diolah dengan regresi tunggal dan jamak. Data kualitatif bersifat tambahan dari hasil pengamatan diperlakukan sebagai data anekdotal.

\section{HASIL DAN PEMBAHASAN}

Pengolahan distribusi, multikolinearitas dan homoscedastisitas menunjukkan data penelitian ini memenuhi persyaratan pengujian. Berikut ini diuraikan analisis data secara deskriptif dan hasil ujia hipotesis, dilanjutkan dengan pembahasan hasil.

Dalam pengukuran modifiabilitas kognisi, skor ACFS adalah skor pasca-tes yang diargumentasikan sebagai level potensial dalam rentang zona perkembangan proksimal ( $\mathrm{M}=40.02, \mathrm{SD}=7.69$, total skor maksimum 60$)$. Karena rentang skor (dalam skala absolut) untuk setiap dimensi berbeda, maka tidak diperbandingkan antar subskala. Klasifikasi $\mathrm{M}=7.95, \mathrm{SD}=2.5$ (maksimum 12), ingatan auditoris $\mathrm{M}=9.81, \mathrm{SD}=2.5$ (maksimum 17), ingatan visual $\mathrm{M}=8.45, \mathrm{SD}=1.38$ (maksimum 13), dan mengenali pola $\mathrm{M}=13.81, \mathrm{SD}=4.16$ (maksimum 18). Secara umum dan pada setiap sub-skala rerata tes pra-pasca menunjukkan perbedaan signifikan (Mpre=28.02, SD=9.14; Mpost=40.02, $\mathrm{SD}=7.69, \mathrm{t}=.80 \mathrm{p}<.01$ ). Dengan demikian dapat dikatakan memang terjadi peningkatan - menunjukkan ada kapasitas kognisi anak untuk dimodifikasi mencapai hasil lebih tinggi. Namun tampak masih ada ruang untuk ditarik lagi agar bisa mencapai hasil yang lebih maksimal, mengingat skor maksimum saat ini belum mencapai plafon skor maksimum.Untuk penelitian kualitatif, bagian hasil memuat bagian-bagian rinci dalam bentuk sub topik-sub topik yang berkaitan langsung dengan fokus penelitian dan kategori-kategori.

Rentang skor MLERS adalah 34-136 dan penelitian ini mendapatkan M=76.05, $\mathrm{SD}=12.402$ (skor data 57-99). Data ini menunjukkan bahwa secara umum tingkat interaksi mediatif guru terhadap anak masih dibawah titik tengah dan mengindikasikan kemampuan guru memediasi proses pembelajaran anak masih 
cukup rendah dibandingkan anjuran teoretik. Secara umum terdapat perbedaan signifikan di mana interaksi mediatif guru di TK dengan status sosial ekonomi menengah atas lebih tinggi daripada TK menengah bawah $(\mathrm{t}=2.647, \mathrm{p}<.05)$. Lebih jauh juga terdapat perbedaan signifikan pada beberapa dimensi di mana kelompok guru dari TK menengah atas lebih tinggi interaksi mediatifnya daripada guru dari TK menengah bawah (Tabel 1).

Tabel 1. Hasil uji perbedaan rerata (t-test) dimensi MLERS berdasarkan SES

\begin{tabular}{|c|c|c|c|c|c|c|}
\hline Dimensi MLERS & SES & Rerata & SD & SEM & $T$ & Sig. (2-tailed) \\
\hline \multirow[t]{2}{*}{ Dorongan \& pujian } & Tinggi* & 5.74 & .96 & .20 & \multirow{2}{*}{$2.59 * * *$} & \multirow{2}{*}{.01} \\
\hline & Rendah** $^{* *}$ & 4.89 & 1.15 & .26 & & \\
\hline \multirow{2}{*}{ Pengaturan tugas } & Tinggi & 18.09 & 2.64 & .55 & \multirow{2}{*}{1.97} & \multirow{2}{*}{.06} \\
\hline & Rendah & 16.47 & 2.65 & .61 & & \\
\hline \multirow[t]{2}{*}{ Mediasi Tantangan } & Tinggi & 2.35 & .89 & .18 & \multirow{2}{*}{$3.17^{* * *}$} & \multirow{2}{*}{.003} \\
\hline & Rendah & 1.53 & .77 & .18 & & \\
\hline \multirow[t]{2}{*}{ Mediasi Perubahan } & Tinggi & 1.57 & .66 & .14 & \multirow{2}{*}{.78} & \multirow{2}{*}{.44} \\
\hline & Rendah & 1.42 & .51 & .12 & & \\
\hline \multirow[t]{2}{*}{ Keterlibatan afektif } & Tinggi & 3.39 & .50 & .10 & \multirow{2}{*}{2.59} & \multirow{2}{*}{.01} \\
\hline & Rendah & 3.00 & .47 & .11 & & \\
\hline \multirow[t]{2}{*}{ Mediasi makna } & Tinggi & 10.78 & 1.83 & .38 & \multirow{2}{*}{1.87} & \multirow{2}{*}{.07} \\
\hline & Rendah & 9.68 & 1.97 & .45 & & \\
\hline \multirow{2}{*}{$\begin{array}{l}\text { Mediasi transendensi/ } \\
\text { ekspansi/perluasan }\end{array}$} & Tinggi & 8.13 & 1.79 & .37 & \multirow{2}{*}{$2.69^{* * *}$} & \multirow{2}{*}{.01} \\
\hline & Rendah & 6.79 & 1.36 & .31 & & \\
\hline \multirow{2}{*}{$\begin{array}{l}\text { Mediasi pengarahan } \\
\text { perhatian/focusing/intenti } \\
\text { on }\end{array}$} & Tinggi & 7.91 & 1.04 & .22 & \multirow[b]{2}{*}{$3.21^{* * *}$} & \multirow[b]{2}{*}{.003} \\
\hline & Rendah & 6.63 & 1.54 & .35 & & \\
\hline \multirow[t]{2}{*}{ Joint regard } & Tinggi & 4.30 & 1.77 & .37 & \multirow{2}{*}{.42} & \multirow{2}{*}{.68} \\
\hline & Rendah & 4.11 & 1.20 & .28 & & \\
\hline \multirow[t]{2}{*}{ Shared Experience } & Tinggi & 1.70 & .77 & .16 & \multirow{2}{*}{1.88} & \multirow{2}{*}{.07} \\
\hline & Rendah & 1.32 & .48 & .11 & & \\
\hline \multirow[t]{2}{*}{ Diferensiasi psikologis } & Tinggi & 12.09 & 2.13 & .44 & \multirow{2}{*}{$2.07^{* * *}$} & \multirow{2}{*}{.05} \\
\hline & Rendah & 10.89 & 1.60 & .37 & & \\
\hline Respon yang tepat & Tinggi & 4.30 & 1.30 & .27 & 52 & 61 \\
\hline & Rendah & 4.11 & 1.15 & .26 &.$J 2$ & \\
\hline
\end{tabular}

Rerata skor interaksi mediatif teman sebaya adalah $30.48(\mathrm{SD}=5.597$, skor data 22-48 dari maksimum 80). Distribusinya sedikit condong (skewed) ke kiri tetapi masih dalam batas normal. Dalam hal ini terindikasi bahwa interaksi mediatif teman sebaya masih sangat rendah dari standar teoretik.

Hasil uji hipotesis pertama menunjukkan ada pengaruh positif interaksi mediatif anak dengan guru terhadap modifiabilitas kognisi anak usia dini di Jakarta $(\mathrm{F}(1,40)=21.15, \mathrm{p}<.001)$. Interaksi mediatif guru yang dialami anak menentukan sekitar $34.6 \%$ varians pada kemampuan kognisi anak untuk dapat ditarik ke level yang lebih tinggi/optimalnya.

Hipotesis kedua yang meninjau kontribusi interaksi mediatif teman sebaya menunjukkan pengaruh yang tidak signifikan terhadap modifiabilitas kognisi anak usia dini di Jakarta dengan nilai $\mathrm{F}(1,40)=2.08, \mathrm{p}=.16$. Hanya $5 \%$ varians modifiabilitas kognisi anak bisa dijelaskan oleh interaksi mediatif teman sebaya dalam penelitian ini. 
Uji pengaruh kualitas lingkungan sekolah menunjukkan nilai $\mathrm{F}(1,40)=16.21$, $\mathrm{p}<.001$ yang membuktikan signifikan dan memberikan kontribusi sebesar $28.8 \%$ dalam menjelaskan varians modifiabilitas kognisi anak usia dini di Jakarta.

Dari kemungkinan skor alat (15-105), rerata skor kualitas lingkungan fisik sekolah adalah 51.81 ( $S D=13.40$, rentang 29-81). Dimensi kualitas fisik mempunyai rerata total 28.19 (maksimum 49) sedangkan dimensi program mempunyai rerata total 23.62 (maksimum 56) dengan rentang yang lebih lebar. Sedangkan rerata per dimensi setelah mempertimbangkan jumlah item adalah 4.04 dan 2.95 secara berturutan. Indikasi ini menunjukkan bahwa kualitas lingkungan sekolah pada sampel penelitian masih lebih baik pada aspek fisik daripada aspek program yang relatif berada dibawah median skor. Secara umum ada perbedaan signifikan antara TK dengan latar sosial-ekonomi menengah atas dan menengah bawah $(\mathrm{M}=56.52$ menengah atas dan 46.11 menengah bawah). Selanjutnya juga ada perbedaan signifikan pada dimensi kualitas fisik $(\mathrm{p}<.01)$ di mana TK SES menengah atas lebih tinggi daripada SES menengah bawah. Untuk dimensi program ada perbedaan juga namun hanya signifikan pada a.05.

Dalam pengujian hipotesis ke-empat, pengolahan regresi berganda dilakukan secara sekuensial/hirarki dimana X1 (MLERS) dimasukkan terlebih dahulu sebelum menambahkan X2 (MLE peers) dan X3 (ECERS-R). Hasil regresi dengan prediktor interaksi mediatif guru saja sama dengan hasil di atas. Berikut ini hasil setelah prediktor interaksi mediatif teman sebaya dan kualitas lingkungan sekolah dimasukkan. Terungkap bahwa variabel X2 (interaksi mediatif teman sebaya) memang tidak berpengaruh signifikan terhadap model persamaan regresi ketika variabel interaksi mediatif guru dan teman sebaya secara bersama-sama dimasukkan. Kontribusinya terhadap varians modifiabilitas kognisi juga hanya 31.2\%, yang berarti kehadiran prediktor X2 justru menurunkan nilai R-sq model ini. Oleh karena itu variabel X2 (interaksi mediatif teman sebaya) dikeluarkan dari model persamaan regresi. Ketika prediktor X3 (kualitas lingkungan sekolah) dimasukkan ke dalam persamaan maka model ini $(X 1+X 3)$ mengakibatkan R-sq berubah dari 0 ke 0.41 . Akan tetapi, walaupun model ini memberikan penjelasan lebih besar daripada jika hanya dengan satu prediktor/ X1 (dari 34.6\% menjadi 40.6\%), tetapi nilai F yang dihasilkan justru menurun (dari 21.15 menjadi 13.33). Dengan kata lain masuknya prediktor X3 menurunkan fitness dari model regresi yang dihasilkan. Oleh karena itu diputuskan bahwa model terbaik adalah regresi dengan satu prediktor saja yaitu X1. Dari ketiga prediktor yang diajukan, hanya interaksi mediatif guru yang secara meyakinkan dapat berkontribusi menjelaskan varians pada modifiabilitas kognisi anak usia dini di Jakarta.

Dari tiga variabel bebas yang diajukan dalam penelitian ini, hanya variabel interaksi mediatif guru yang secara signifikan berkontribusi terhadap modifiabilitas kognisi anak usia dini di Jakarta. Sementara itu gambaran umum dari setiap variabel bebas itu menunjukkan bahwa kondisi pada sampel penelitian ini masih di bawah anjuran. Dari seluruh kajian tentang interaksi mediatif (MLE) yang dapat diakses sebagai rujukan, penelitian ini hampir merupakan satu-satunya yang berbasis pengamatan alamiah tanpa intervensi apapun. Ada kemungkinan setting natural mempengaruhi hasil penelitian ini walaupun tak menutup kemungkinan hasil ini memang mengindikasikan kondisi riil pada TK di Jakarta. 
Upaya untuk melakukan pengamatan beberapa hari guna menetralisir kemungkinan guru dan anak tidak berperilaku wajar selama kegiatan di sekolah sudah dilakukan. Secara kualitatif teramati bahwa mayoritas TK cenderung untuk menjalankan pembelajaran berpusat pada guru; dari komentar guru dalam kelas ada kemungkinan guru punya pandangan bahwa proses belajar yang "baik" adalah ketika anak terpusat perhatiannya hanya kepada guru, mengerjakan tugas dan tidak berbicara/berinteraksi dengan teman.

Dalam masalah rendahnya interaksi mediatif teman sebaya, selain karena kemungkinan format program di TK yang menjadi sampel penelitian ini - lebih berpusat pada guru, memilah belajar dan bermain - ada kemungkinan lain bahwa guru memang tidak memandang penting belajar kolaboratif pada pendidikan anak usia dini. Penelitian ini tidak melakukan wawancara untuk mendalami sikap dan pandangan guru tentang interaksi mediatif khususnya antar teman sebaya. Kasus pada sebuah TK sampel menunjukkan dengan jelas betapa guru yang "baik" hampir sama sekali tidak menghargai interaksi antar teman sebaya di dalam kelasnya. Kiranya jelas diperlukan pendalaman mengenai hal ini.

Umumnya penelitian MLE teman sebaya bersetting laboratorium/ eksperimen, termasuk memberikan pelatihan kepada teman sebaya untuk melakukan interaksi mediatif (a.l. Tzuriel \& Shamir, 2010; Tzuriel \& Caspi, 2017). Dalam penelitian ini ditunjukkan bahwa dalam situasi natural dan pada anak usia dini terdapat pengalaman belajar dengan mediasi teman sebaya. Namun jumlah kejadiannya terlalu minim untuk dapat secara signifikan berkontribusi.

ECERS-R merupakan instrumen yang biasa digunakan para pengawas pendidikan anak usia dini di berbagai negara dan sudah diterjemahkan ke dalam banyak bahasa. Dalam salah satu diskusi pada situs resmi penerbit alat ini (www.tcp.com) ditemukan bahwa untuk penggunaan di negara sedang berkembang alat ini memunculkan isu rendahnya kualitas lingkungan PAUD. Apakah hal ini juga terjadi di Indonesia? Berpegang pada standar praktik sesuai perkembangan maka penelitian ini tidak mengadaptasi standar penilaian ECERS-R. Adaptasi hanya dilakukan untuk masalah konteks seperti musim. Dan kenyataannya skor TK yang menjadi sampel penelitian ini memang masih dibawah anjuran, bahkan untuk TK yang berlatar-belakang SES menengah atas. Dalam penelitian ini ditemukan bahwa SES lebih tinggi tidak menjamin kualitas lingkungan terkait program di sekolah. Perbedaan signifikan lebih muncul pada kualitas lingkungan fisik semata. Hal ini tentunya perlu mendapat perhatian dari pihak terkait, karena keberadaan barang meskipun berwujud perlengkapan/mainan beraneka rupa tidak otomatis akan banyak berkontribusi pada perkembangan kognitif anak. Penelitian ini telah membuktikan pula apa yang menjadi klaim Feuerstein, Feuerstein \& Falik (2010) bahwa jika tidak diiringi dengan pengalaman belajar yang dimediasi oleh orang yang lebih kompeten - yang dalam penelitian ini guru - maka potensi terbaik perkembangan kognitif anak sulit tercapai. Pembuktian ini mematahkan asumsi dasar bahwa kontak/adaptasi terhadap lingkungan akan secara otomatis merangsang perkembangan kognitif anak (Falck, 2020).

Modifiabilitas kognisi yang relatif masih kurang optimal tampaknya seiring dengan temuan umum tentang anak usia dini di Indonesia yang lemah dalam perkembangan kognitif (Hasan, A.; Hyson, M.; Chang, 2012; Suryadarma \& Jones, 2013). Penelitian Ulni dan Suparno (2020) yang lebih terkini juga menunjukkan kelemahan anak dalam memahami pola. Walaupun tidak berbasis pada konstruk 
yang persis sama dalam hal perkembangan kognitif, namun temuan penelitian ini mengindikasikan bahwa anak-anak di kota Jakarta dengan konteks TK menengah atas pun ternyata mempunyai masalah dalam hal optimalisasi perkembangan kognitifnya.

Hasil kajian Apriyanti (2017) menyatakan bahwa pengetahuan konseptual guru umumnya memadai. Sementara itu Tatminingsih (2019) menyimpulkan bahwa peran guru tak tergantikan. Bahkan, dalam pembuktian bahwa pengembangan kognitif dapat dilakukan melalui pengelolaan lingkungan belajar yang tentunya dilakukan guru (Yaswinda et al., 2021), namun kelemahan fungsi kognitif pada anak dalam memahami pola ternyata tetap diatribusikan pada guru yang kurang memfasilitasi (Ulni \& Suparno, 2020).

Penelitian Schweinhart (2007) berhasil membuktikan tingkat pengembalian yang sangat besar untuk investasi penyelenggaraan pendidikan anak usia dini yang berkualitas terutama dalam mengatasi kemiskinan. Jika mengacu pada pentingnya peranan guru sebagai komponen sebuah pendidikan anak usia dini yang berkualitas, maka temuan penelitian ini perlu diwaspadai. Secara umum guru pendidikan anak usia dini setidaknya di DKI Jakarta masih perlu meningkatkan kemampuannya mengolah proses pembelajaran anak melalui interaksi mediatif yang lebih baik kualitasnya. Anak-anak dengan latar belakang ekonomi rendah membutuhkan dorongan agar dapat mengembangkan rasa percaya diri, menerima tantangan, memperluas cakrawala berpikirnya. Tanpa dasar ini layanan PAUD pada masyarakat sosial ekonomi menengah bawah kehilangan maknanya. Penelitian menunjukkan bahwa pembelajaran yang bersifat konten akademis sempit pada program anak usia dini kurang efektif memberikan dorongan kemajuan yang akan bertahan lama pada anak (Chambers et al., 2010). Sebaliknya, yang diperlukan justru pembentukan growth mindset temuan Dweck yang terjadi melalui umpan balik lingkungan - termasuk guru sejak anak usia dini - hingga anak memiliki mastery orientation (Moore \& Shaughnessy, 2012). Dengan demikian maka pembekalan untuk memastikan kemampuan para guru pun harus mencakup penguasaan cara memberi rambatan, umpan balik dan semacamnya.

Hasil penelitian ini masih relatif searah dengan temuan yang disajikan oleh (Kozulin, 2002a, 2002b) walaupun penelitian ini mengkaji perilaku guru alih-alih ibu. Dimensi yang memunculkan perbedaan status sosial ekonomi dalam penelitian ini juga mencakup transendensi, pemaknaan dan perasaan kompeten. Kenyataan bahwa dimensi-dimensi itu juga yang paling bermakna bagi perkembangan anak semakin mengukuhkan pentingnya memastikan bahwa para guru pendidikan anak usia dini menguasai cara memediasi transendensi, pemaknaan dan perasaan kompeten.

Penelitian ini memiliki keterbatasan dalam jumlah sampel, khususnya untuk menghasilkan analisis yang lebih konklusif. Namun penggunaan metode pengamatan natural dalam penelitian ini telah berkontribusi melengkapi pengetahuan terkait interaksi mediatif dengan guru dan teman sebaya. Terbukti pula bahwa pengalaman anak dalam berinteraksi mediatif dengan guru sebaiknya diteliti melalui pengamatan.

Perlu penelitian lebih lanjut untuk mendalami variabel penelitian ini yang masih sangat jarang diteliti di Indonesia. Beberapa saran adalah 1) mendalami mengenai pengetahuan dan pandangan guru tentang interaksi mediatif; 2) meneliti kelompok anak dengan status ekonomi sosial menengah atas dan kelas yang interaksi mediatif gurunya tinggi pada program yang memberi ruang bagi kegiatan bebas, mandiri bersama teman sebaya dan dalam lingkungan sekolah yang berkualitas baik. Dalam hal ini diperlukan penapisan kualitas interaksi mediatif dan program terlebih 
dahulu mengingat penelitian ini menunjukkan bahwa sekolah dengan biaya cukup mahal (SES tinggi) tidak selalu menjamin interaksi mediatif guru, teman sebaya dan kualitas lingkungan sekolah khususnya program yang baik/tinggi pula;3) mendalami modifiabilitas kognisi secara kualitatif sehingga dapat ditemukan pula secara lebih rinci unsur masalah yang mungkin terjadi pada anak usia dini di Indonesia - apakah masalah pada soal input informasi, pengolahan atau soal pengeluarannya.

\section{SIMPULAN}

Dari tiga elemen pendidikan anak usia dini - interaksi mediatif guru, teman sebaya dan kualitas lingkungan fisik sekolah, hanya interaksi mediatif dengan guru yang signifikan berkontribusi terhadap modifiabilitas kognisi anak TK B di Jakarta. Implikasi terpenting dari penelitian ini adalah perlunya pihak sekolah dan pemangku kepentingan terkait untuk memberi perhatian lebih banyak pada kemampuan guru dalam melakukan interaksi mediatif bagi perkembangan kognisi anak. Hal ini terlebih pada kondisi sekolah yang karena keterbatasannya harus memilih antara mengalokasikan dana pengembangan guru atau kualitas lingkungan fisik sekolah. Implikasi lain adalah diperlukannya peningkatan kesempatan anak untuk lebih bebas bermain dan belajar bersama teman sebayanya.

\section{DAFTAR PUSTAKA}

Apriyanti, H. (2017). Pemahaman Guru Pendidikan Anak Usia Dini Terhadap Perencanaan Pembelajaran Tematik. Jurnal Obsesi: Jurnal Pendidikan Anak Usia Dini, 1(2), 111. https://doi.org/10.31004/obsesi.v1i2.22

Beatty, A., Berkhout, E., Bima, L., Coen, T., Pradhan, M., \& Suryadarma, D. (2018). Indonesia Got Schooled: 15 Years of Rising Enrolment and Flat Learning Profiles. In RISE Working Paper 18/026.

Boduroglu, A., Shah, P., \& Nisbett, R. E. (2009). Cultural differences in allocation of attention in visual information processing. Journal of Cross-Cultural Psychology, 40(3), 349-360. https://doi.org/10.1177/0022022108331005

Buchori, M. (2002). Kurikulum Untuk Melahirkan Generasi Pembaru. In T. D. Widiastono (Ed.), Pendidikan Manusia Indonesia (p. 2002). Penerbit Buku Kompas.

Chambers, B., Cheung, A., Slavin, R. E., \& Laurenzano, M. (2010). Effective Early Childhood Education Programs : A Systematic Review Dewi Smith Success for All Foundation. In Best Evidence Encyclopedia (BEE) (Issue September).

Falck, S. (2020). The psychology of intelligence. In The Psychology of Intelligence. Routledge Classics. https:// doi.org/10.4324/9781003042365

Farver, J. A. M., \& Wimbarti, S. (1995). Indonesian Children's Play with Their Mothers and Older Siblings. Child Development, 66(5), 1493-1503. https://doi.org/10.1111/j.14678624.1995.tb00947.x

Feuerstein, R., Feuerstein, R. S., \& Falik, L. H. (2010). Beyond smarter: Mediated learning and the brain's capacity for change. In Beyond smarter: Mediated learning and the brain's capacity for change. Teachers College Press. https://www.lib.uwo.ca/cgibin/ezpauthn.cgi?url=http://search.proquest.com/docview/906332187?accountid=1 5115\%0Ahttps:/ / oculuwo.primo.exlibrisgroup.com/openurl/01OCUL_UWO/01OCUL_UWO:UWO_DEF AULT??url_ver=Z39.88-2004\&rft_val_fmt=info:ofi/fmt:kev:mtx:book\&genr

Feuerstein, R., Klein, P. S., Tannenbaum, A. J., \& International Center for Enhancement of Learning Potential (ICELP). (1994). Mediated learning experience (MLE): theoretical, psychosocial and learning implications (R. Feuerstein, P. S. Klein, \& A. J. Tannenbaum (eds.)). Freund Publising House Ltd. 
Geary, D. C. (2006). The origin of mind: Evolution of brain, cognition, and general intelligence. In The origin of mind: Evolution of brain, cognition, and general intelligence. American Psychological Association (APA). https:/ / doi.org/10.1037/10871-000

Hallpike, C. R., \& Wertsch, J. V. (1987). Culture, Communication, and Cognition: Vygotskian Perspectives. Man, 22(1), 220. https:/ / doi.org/10.2307/2803027

Harms, T., Clifford, R. M., \& Cryer, D. (1999). Early childhood environment rating scale. Choice Reviews Online, 36(06), 36-3454-36-3454. https:// doi.org/10.5860/choice.36-3454

Hasan, A.; Hyson, M.; Chang, M. C. (Eds). (2012). Early Childhood Education and Development in Poor Villages of Indonesia. Worldbank.

Haywood, H. C., \& Lidz, C. S. (2006). Dynamic assessment in practice: Clinical and educational applications. In Dynamic Assessment in Practice: Clinical and Educational Applications. https:// doi.org/10.1017/CBO9780511607516

Jensen, E. (2006). Enriching the Brain. Jossey-Bass.

King, A. (1997). ASK to THINK-TEL WHY®@: A model of transactive peer tutoring for scaffolding higher level complex learning. Educational Psychologist, 32(4), 221-235. https:// doi.org/10.1207/s15326985ep3204_3

Kozulin, A. (2002a). Guest Editorial: Mediated Learning Experience - from Theory to Classroom Application. School Psychology International, 23(1), 5-6.

Kozulin, A. (2002b). Sociocultural Theory and the Mediated Learning Experience .pdf. School Psychology International, 23(1), 7-35.

Lidz, C. (2008). Early Childhood Assessment. In Early Childhood Assessment. Wiley. https:// doi.org/10.17226/12446

McMaster, K. L., Fuchs, D., \& Fuchs, L. S. (2006). Research on peer-assisted learning strategies: The promise and limitations of peer-mediated instruction. Reading and Writing Quarterly, 22(1), 5-25. https:/ / doi.org/10.1080/10573560500203491

Moore, T.-L. M. B., \& Shaughnessy, M. F. (2012). Carol Dweck's Views on Achievement and Intelligence: Implications for Education. Research Journal of Organisational Psychology and Educational Studies, 1(3), 174-184.

Munro, R. L., \& Munro, R. H. (n.d.). Cross-Cultural Human Development. Jason Aronson Inc.

NAEYC. (2009). Developmentally Appropriate Practice in Early Childhood Programs Serving Children from Birth through Age 8.

No authorship indicated. (1993). Practitioner's Guide to Dynamic Assessment. PsycCRITIQUES, 38(7). https:// doi.org/10.1037/033558

OECD/Asian Development Bank. (2015). Education in Indonesia: Rising to the Challenge. OECD Publishing, Paris. https://doi.org/10.1787/9789264230750-en

Pnina S Klein. (2003). A mediational approach to early intervention.pdf (J. M. Martinez, J. Lebeer, \& R. Garbo (eds.); pp. 60-80). Editorial Bruno.

Rogoff, B., Mistry, J., Göncü, A., Mosier, C., Chavajay, P., Heath, S. B., \& Goncu, A. (1993). Guided Participation in Cultural Activity by Toddlers and Caregivers. Monographs of the Society for Research in Child Development, 58(8), i. https:// doi.org/10.2307/1166109

Schweinhart, L. J. (2007). Outcomes of the High/Scope perry preschool study and michigan readiness program. Journal OF Education and Psychological Consultation, 17(1), 87.

Seok-Hoon, S. A., Pou, L. K.-H., \& Tan, O.-S. (2003). Mediated Learning Experience with Children : Applications Across Contexts (S. A. Seok-Hoon, L. K.-H. Pou, \& O.-S. Tan (eds.)). McGraw-Hill Education (Asia).

Shamir, A., \& Tzuriel, D. (2002). Peer mediation: A novel model for development of mediation skills and cognitive modifiability of young children. Learning Potential Assessment and Cognitive Training: Actual Research Perspectives in Theory Building and Methodology, 7, 365-383.

Smeru. (2016). Studi Diagnostik Pembelajaran Pendidikan Dasar di Kabupaten Lombok Utara Provinsi Nusa Tenggara Barat.

Suryadarma, D., \& Jones, G. W. (2013). Education in Indonesia. In D. Suryadarma \& G. W. 
Jones (Eds.), Education in Indonesia. ISEAS. https:/ / doi.org/10.4324/9780429397981-5

Tatminingsih, S. (2019). Alternatif Stimulasi Kemampuan Kognitif melalui Penerapan Model Pembelajaran Berbasis Permainan Komprehensif. Jurnal Obsesi : Jurnal Pendidikan Anak Usia Dini, 3(1), 183. https:/ / doi.org/10.31004/obsesi.v3i1.130

Tiatri, S. (2001). Penerapan Prinsip MLE oleh Guru dan Motivasi Berprestasi Siswa terhadap Prestasi Belajar. Fakultas Psikologi - Universitas Indonesia.

Tilaar, H. A. R. (2004). Multikulturalisme: Tantangan-Tantangan Global Masa Depan Dalam Transformasi Pendidikan Nasional [Multiculturalism: Future Global Challenges in National Education Transformation]. PT. Grasindo.

Tzuriel, D., \& Caspi, R. (2017). Intervention for peer mediation and mother-child interaction: The effects on children's mediated learning strategies and cognitive modifiability. Contemporary Educational Psychology, 49, 302-323. https://doi.org/10.1016/j.cedpsych.2017.03.005

Tzuriel, D., \& Shamir, A. (2010). Mediation Strategies and Cognitive Modifi ability in Young Children as a Function of Peer Mediation With Young Children Program and Training in Analogies Versus Math Tasks. 9(1), 48-72. https:/ / doi.org/10.1891/1945

Ulni, E. K., \& Suparno, S. (2020). Pengembangan Model Pembelajaran Sorting Predict-think Discovery untuk Meningkatkan Kemampuan Mengenal Pola. Jurnal Obsesi: Jurnal Pendidikan Anak Usia Dini, 5(1), 303. https:/ / doi.org/10.31004/obsesi.v5i1.576

UNESCO. (2005). Laporan Review Kebijakan : Laporan Review Kebijakan: Pendidikan dan Perawatan Anak Usia Dini di Indonesia. Diunduh Agustus, 66. http://xa.yimg.com/kq/groups/19455984/893872425/name/paud versi unesco 2005.pdf

Wood, E., \& Attfield, J. (2005). Play, learning and the early childhood curriculum. In Play, Learning and the Early Childhood Curriculum. SAGE Publications Inc. https://doi.org/10.4135/9781446280393

Yaswinda, Y., Yulsyofriend, Y., \& Sari, H. M. (2021). Analisis Pengembangan Kognitif dan Emosional Anak Kelompok Bermain Berbasis Kawasan Pesisir Pantai. 5(2), 996-1008. https://doi.org/10.31004/obsesi.v5i2.711 